\title{
ACCIDENTAL OVER-DOSE OF ALFATHESIN UNDER GENERAL ANAESTHESIA: CASE REPORT
}

\author{
N.B. BøgGild-MAdsen and T. CARGNelli
}

A 43-YEAR-OLD WOMAN weighing $43 \mathrm{~kg}$ was operated on for metastasis of a mammary carcinoma in the right parieto-occipital region of the brain. Pre-operatively the patient was confined to bed, but was otherwise in reasonable condition. She was receiving prednisone $15 \mathrm{mg}$ daily. The rectal temperature was $37^{\circ} \mathrm{C}$.

General anaesthesia was administered using alfathesin $1 \mu \mathrm{l} / \mathrm{kg} /$ minute with fentanyl, pancuronium and a 2:1 mixture of nitrous-oxide and oxygen. Alfathesin was given as a continuous intravenous infusion with Ringer's solution containing 10 per cent alfathesin.

Respiration was controlled with an Elema Servo-Respirator 900 . End-tidal carbon dioxide was measured continuously by a Godart capnograph and kept at 3.5 to 4 per cent. EKG, pulse frequency and respiratory frequency were monitored with Hewlett-Packard recorders. Brachial artery blood pressure was automatically measured every two minutes by an Arteriosonde Roche 1217. Control measurements were made by the auscultatory method on the opposite brachial artery approximately every 10 minutes. The room was air-conditioned. The temperature was kept at $21^{\circ} \mathrm{C}$ and the humidity at 60 per cent.

While the metastasis was being removed, bleeding occurred, which required blood transfusion to be given as well as infusion of Haemaccel** and Ringer's solution. After the bleeding was controlled, the blood pressure was $70 \mathrm{~mm} \mathrm{Hg}$ systolic. The infusions were continued for a short time and, during this period, the whole of the remaining fluid in the alfathesin drip, which contained $35 \mathrm{ml}$ pure alfathesin, was accidentally given over a period of two minutes. The alfathesin bottle was clearly marked and was being given through a separate intravenous cannula, all other infusions being given through another cannula. During the entire operation all infusions were

N.B. Bøggild-Madsen, reservelæge and T. Cargnelli, reservelæge, Department of Neuroanaesthesiology, Aarhus kommunehospital, University Hospital of Aarhus, DK-8000 Aarhus C, Denmark.

${ }^{*}$ Haemacce ${ }^{* 0}$ is polygelinum, a plasma substitute with molecular weight 35000 . It contains chains of polypeptides.

Canad. Anaesth. Soc. J., vol. 25, no. 3, May 1978 warmed and kept at $37^{\circ} \mathrm{C}$ by a Heto 02 c 640 electrical blood warmer.

The mistake was immediately detected. The blood pressure stayed at $70 \mathrm{~mm} \mathrm{Hg}$ systolic; the pulse was 96 . Ten minutes later the blood pressure was $100 \mathrm{~mm} \mathrm{Hg}$ systolic and the pulse 90 . No change was noted in the electrocardigram. The skin was pink, dry and warm with visible veins. No cyanosis was seen.

The anaesthetic was continued for a further 135 minutes with the same method and same dosage as before the accident, as no toxic effects had been observed and as it was considered important to keep the patient anaesthetized without possibility of recovery until the end of the operation.

Post-operatively the rectal temperature was monitored by an Ellab Electrical Universal Thermometer TE 5 and found to be $31^{\circ} \mathrm{C}$. Because of this and in order to treat possible cerebral oedema, it was decided to give 20 hours hyperventilation on a respirator.

Seven hours after the operation the rectal temperature was $38.5^{\circ} \mathrm{C}$ and 12 hours after the operation the patient was completely awake. There was no nausea after the anaesthetic. Following the operation there was persistent hemiparesis, which was attributed to the operative procedure itself. If the $3 \mathrm{ml}$ of alfathesin given for induction is included, then a total of 48 $\mathrm{ml}$ pure alfathesin was given over a period of 4 hours 30 minutes (together with pancuronium 10 mg and fentanyl $0.550 \mathrm{mg}$ ).

On questioning the patient the next day it was found that she had complete amnesia for the period on the respirator, but could clearly remember the induction. After seven months, with increasing cerebral symptoms, the patient went into a coma and died.

\section{Discussion}

The advantage of using alfathesin in neuroanaesthesia is that, like barbiturates, it lowers the intracranial pressure ${ }^{1}$, but gives a more rapid and complete awakening ${ }^{2}$, which is useful in the surgical assessment of the patient after anaesthesia. It is also considered to be a safer anaesthetic 
agent than thiopentone, although over-dosage on induction is described and several cases of complete circulatory collapse have been documented. ${ }^{3}$ The blood pressure falls on induction if too large a dose is given, or if it is given too quickly. However, lowering of the blood pressure is diminished if alfathesin has been given before. ${ }^{5}$ Peripheral vasodilatation increases the fall in blood pressure with the administration of alfathesin. ${ }^{6.7}$ Tachycardia due to alfathesin has been described during induction, ${ }^{4}$ but Savege did not find that this always occurred. ${ }^{8}$ Cundy found that alfathesin given during anaesthesia for prostatectomy could protect against dysrhythmias in the electrocardiogram."

Over-dosage under anaesthesia with continuous infusion of alfathesin, has not been previously described, as far as we know. In our case, it is worth noting that the ECG remained normal after the over-dosage and that there was no lowering of blood pressure. The post-anaesthetic body temperature of only $31^{\circ} \mathrm{C}$ can not be explained as being due to administration of cold fluids or cooling from the environment. The remarkable widespread peripheral vasodilatation with warm skin is supposed to be caused directly by alfathesin, ${ }^{7}$ so this agent could have increased the loss of heat from the body if the temperature of the skin was increased.

Unfortunately no skin or rectal temperatures were measured during the operation, but as all normal temperature protecting procedures were followed, it is concluded that the hypothermia must be related to the overdose of alfathesin.

That the amount of alfathesin given was large is underlined by the fact that under normal conditions the over-dose would have been enough to anaesthetize the patient for a total of 13 hours with a standard dose of $1 \mu \mathrm{l} / \mathrm{kg} /$ minute. Experiments on mice emphasize the high therapeutic index for alfathesin of 30.4 against 5.9 to 8.5 for thiopentone, methohexitone, propanidid and ketamine. ${ }^{10}$

It is the opinion of the authors that the equivalent over-dose of another anaesthetic agent would have been fatal for the patient. Nevertheless, measures should be taken to prevent a similar occurrence. The manufacturers of alfathesin (GLAXO) have now, at our request, prepared special red labels to stick on the infusion bottles.

\section{SUMMARY}

Under general anaesthesia, $35 \mathrm{ml}$ of alfathesin was accidentally injected intravenously. There was no change in the pulse rate and blood pressure. However, two hours later, at the end of the operation, the rectal temperature was $31^{\circ} \mathrm{C}$. There were no long-lasting effects of the overdose.

\section{RÉsumé}

Au cours d'une anesthésie générale, $35 \mathrm{ml}$ d'Althesin furent administrés accidentellement par voie intraveineuse. On n'observa pas de modifications de la fréquence cardiaque et de la pression artérielle. Cependant, à la fin de l'intervention, soit deux heures après l'injection, on notait que la température rectale était à $31^{\circ} \mathrm{C}$. Aucune conséquence à long terme n'a été observée.

\section{REFERENCES}

1. Turner, J.M., Coroneos, N.J., Gibson, R.M., Powell, D., Ness, M.A., \& MCDowall, D.G. The effect of Althesin on intracranial pressure in man. British Journal of Anaesthesia 45: 168 (1973).

2. Carson, I.W. Group trial of Althesin as an intravenous anaesthetic. Postgraduate Medical Joumal, June Supplement, 108 (1972).

3. Clarke, R.S.J., Dundee, J.W., GarretT, R.T., MCARDLE, G.K., \& SUTTON, J.A. Adverse reactions to intravenous anaesthetics. British Journal of Anaesthesia, 47: 575 (1975).

4. Savege, T.M., Foley, E.l., Coultas, R.J., Walton, B., Strunin, L., Simpson, B.R., \& SCotr, D.F. CT 1341: some effects in man. Anaesthesia, 26: 402 (1971).

5. TAKAHASHI, T. Waveband analysis of EEG patterns during anaesthesia produced by Althesin. Postgraduate Medical Journal, June Supplement, 96 (1972).

6. DU CAILER, J. The effects in man of infusions of Althesin with particular regard to the cardiovascular system. Postgraduate Medical Journal, June Supplement, 72 (1972).

7. Aronski, A., Kubler, A., Majda, A., \& JankowsKa, M. Cardiovascular effects of Althesin. Anaesthesia, 31: 195 (1976)

8. Savege, T.M., Colvin, M.P., Weaver, E.J.M., Bond, C., DRaKe, J., \& INNiss, R. A comparison of some cardio-respiratory effects of Althesin and Ketamine when used for induction of anaesthesia in patient 5 with cardiac disease. British Journal of Anaesthesia, 48: 1071 (1976).

9. CUNDY, J.M. The anti-dysrhythmic effect of Althesin. Anaesthesia, 28: 544 (1973).

10. Davis, B. \& PEARCE, D.R. An introduction to Althesin. Postgraduate Medical Journal, June Supplement, 13 (1972). 